\title{
Mobility and Social Cohesion in the Splintered City: Challenging Technocentric Transport Research and Policy-making Practices
}

\begin{abstract}
This paper argues that dominant research practices in the urban transport field add to rather than subtract from social cohesion and mobility inequities. While this is recognised as an on-going political struggle, it is also explained through a failure to mobilise consistently a broad definition of social cohesion in transport research and policy-making; and a technology fixation among communities of transport research and practice, particularly in the commissioning of European Commission research. Elements of a new urban mobility agenda are proposed to address mobility challenges and to improve the fostering of urban social cohesion.
\end{abstract}

\section{Introduction}

The ability to access everyday goods and services, and interact with other people is a fundamental building block of a cohesive urban environment. Urban mobility not only allows access to city resources but also shapes the everyday experience of the city and society. Urban transport networks are critical in framing the mobility opportunities of individuals and thus in shaping social practices and networks of human interaction within various spheres of city life.

Mobility opportunities, however, are unevenly distributed among social groups and across the space of the city. A number of well-known and thoroughly studied processes, such as privatisation, deregulation and marketisation in urban service provision, have led to more differentiation in access to services often now more greatly mediated by an ability to pay. The idea of a 'splintered city' (Graham and Marvin, 2001) points to increasing polarisation whereby not only individuals but whole neighbourhoods exhibit problems of connectedness in relation to employment, consumption, leisure and social life. We argue that, despite growing multidisciplinarity in transport research, sometimes embracing social cohesion issues, these are often poorly understood and underplayed in the policy-making and planning practices in European cities. This systematically, although often unconsciously, reinforces unevenness in the socio-spatial distribution of mobility opportunities (Whitelegg, 1997; Banister, 2005).

In this paper, after Novy et al. (this issue), we understand social cohesion as a four-dimensional problématique embracing socioeconomic, cultural, political and socio-environmental dimensions. We also recognise that the 'problematisation' of social cohesion is a dynamic and conflictive process rather than a value-free decision or a pre-defined consensus. Hence, we take on board a dialectical understanding of processes of exclusion and inclusion, coherence and fragmentation, connection and disconnection, and empowerment and disempowerment that operate in and through urban mobility field. To this purpose, we mobilise a holistic conceptualisation of urban mobility wherein transport serves individuals and social groupings not only as a utilitarian means of access to goods and services, but also as a crucial determinant of connectedness to diverse human networks and spaces of social integration. This conceptualisation also promotes an examination of social justice concerns relating to the rising unevenness of transport provision and an exploration of the potentials of urban mobility to build more cohesive urban societies. We argue for more transdisciplinarity in transport research and policy-making, 
and the mobilisation of more contextualised qualitative insights on urban mobility in the provision of transport solutions.

For this purpose, we address the following questions. Does transport research (in a diversity of disciplines) embrace the issue of social cohesion in its various dimensions? How is urban social cohesion considered in the dominant methodologies associated with the consideration of transport policy? How can social cohesion be fostered through innovative transport research and policy? In addressing these questions, the next section looks at research in the area of social cohesion and urban transport to explore different traditions of researching relations between urban transport and social cohesion. Sections 3 and 4, which focus on European Commission research in particular, examine the deficiencies of dominant technocentric transport research and policy-making practices. Sections 5 and 6 propose a new urban mobility agenda to address the challenges of social cohesion in the city and to inform future research and policy in building more cohesive urban societies.

\section{Social Cohesion and Urban Transport Research: An Historical Overview}

Issues of social cohesion with regard to urban transport have a long history of research under various disciplines from economics and engineering to human geography, sociology and cultural anthropology. Questions of urban inequality and socio-spatially inequitable distribution of mobility opportunities have been present in urban sociology since the classical works of the Chicago school (for example, Park et al., 1925; Wirth, 1928) and are continued within gentrification studies (for example, Lin, 2002; Danyluk and Ley, 2007), as well as in ethnic and racial studies (for example, Massey and Denton, 1993; Canon 1998).

This latter field begins to overlap with work on environmental justice (see Cook and Swyngedouw, this issue) which, since the 1960s, has highlighted how low-income urban neighbourhoods suffer a greater than average exposure to the noise, pollution and environmental hazards resulting from the transport choices of others while also having fewer mobility opportunities themselves (Bullard et al., 2004; Whitelegg, 1997; Vasconcellos, 2001). The greater exposure of poor populations - that are more likely to live near flightpaths, busy rail infrastructure and motorway junctions - to road accidents and environmental hazards has recently become particularly severe in eastern Europe and the global South, where rapid motorisation was not followed by major road improvements (see Ministerstwo Infrastruktury, 2004; Pucher et al., 2007). Urban planning processes of the mid and late twentieth century were culpable in exacerbating these issues as large social housing developments were constructed on urban peripheries, often poorly connected to centres of urban commerce.

Methodologically, the effects of these processes have been captured by researchers, sometimes using time-space analysis influenced by geographers such as Torsten Hägerstrand (1974), which points to the differences in opportunities for various social groups depending on the locational characteristics of their homes and their access to transport technologies, particularly the private car. Such a tradition continues, perhaps most promisingly in contemporary life-course analysis through the work of, among others, Grieco and Macdonald (2007) and Jarvis (2005). Certainly the issues arising from the social distribution of mobility opportunities and externalities arising from it are still relevant to the discipline and catalyse grassroots initiatives in Europe, the US, Canada, Australia and the developing world (see Cook and Swyngedouw, this issue).

In transport studies, the interest in social cohesion was for many years limited to equity issues understood as the fulfilment of the basic needs of vulnerable populations (the unemployed, the elderly, 
people with disabilities, single-parent families, etc.). To some extent, in more recent studies, the focus has shifted from the socioeconomic dimensions of social cohesion-i.e. social equity-to more multidimensional analyses of social exclusion and inclusion through urban mobility. In both cases, however, there is a trend towards fragmenting societies into groups such as the elderly with a parallel promotion of a solution such as community transport. This drift towards a 'single problem, single answer' way of thinking has held back a richer understanding of the multiple ways in which transport and mobility issues are implicated in broader processes of social cohesion. With this in mind, the social cohesion problématique is now being intensively researched by transport geographers and transport planners in more systemic ways that point to socioeconomic, cultural and spatial factors impacting on the mobility opportunities of individuals and, in turn, to the impacts of diverging mobility situations on both the life opportunities of individuals and broader societal issues (for example, Lucas and Stanley, 2003; Hine and Mitchell, 2003; Rajé, 2004; Kemming and Brinkmann, 2007).

The multiple interplays between the changing morphologies of cities, transport infrastructures and policies and social interaction, on the one hand, and urban mobility, on the other, are addressed amongst others by Church et al. (2000) who provide a seven-fold categorisation of the ways in which transport exclusion arises, encompassing such factors as physical barriers in the built environment, privatisation of public spaces, dispersal of facilities and services, as well as geographical, economic and fear-based exclusion, and time poverty. Such analyses point to increasingly complex mobility inequalities which: relate both to spatial and social accessibility; take subtle and hidden forms and encompass large swathes of the population; and, disproportionately affect certain groups according to age, ethnicity and gender among other variables.

Moreover, the acknowledgement of movement and mobility as critical keys to individual freedom, independence, access to work, education, health and leisure and thus as prerequisites for intragenerational and intergenerational social mobility in the broader sense (Bonss and Kesselring, 2001; SEU, 2003), as well as the impacts of mobility opportunities on community life and political participation and empowerment (Preston and Rajé, 2007; Häussermann, 2000) have recently become more apparent. Such work is also being undertaken with a consideration of access to information and communication technologies seen as both substitutive and complementary to physical mobility (for example, Lyons, 2009; Hine and Grieco, 2003; Zinnbauer, 2007). These research attempts, while examining how differences in mobility opportunities affect not only particular households but also prove to be disruptive for community life and social capital at the local level, explore the complex links between socioeconomic and political dimensions of social cohesion (see Novy et al., this issue), and between personal mobility and the social cohesion of the city as a whole. Mobility exclusion correlates with social isolation and estrangement and thus undermines all forms of sociability including participation in civil organisations, local associations and family life. The withdrawal of large numbers of people from broader society and the impacts of weakening social bonds in deprived neighbourhoods create further implications for levels of crime and the ensuring of social order in the city (Beckmann $e t$ al., 2007a, 2007b).

Complementing these considerations is a recognition of urban mobility - in the expanding work on 'mobilities' in particular - as an end in itself (for example, Urry, 2007) rather than just, in economists' terms, a derived demand, a means of fulfilling basic needs. Such recognition of relationality between experienced urban mobility and identities of travellers breaks with the consideration of mobility as dead time in favour of looking at travel time as meaningful social experience and considering transport interchanges, bus stops, underground trains and buses as public spaces where individuals and groups create and negotiate meanings, cultures and identities (Jain and Lyons, 2008; Jensen, 2009; Sheller and 
Urry, 2006). In such work, transport systems are considered political sites of the everyday, wherein both inclusive and discriminatory practices are not only enacted, but also reshaped through different events, encounters and processes.

However, how far such research has changed the dominant practices of transport research and practice communities is a moot point. There is a division between the academic work already cited and the practice-oriented and policy-informing research commissioned by the transport industry and governmental departments to the exclusion of social science in particular (Terry, 2004). European Commission research - interdisciplinary and transsectoral in its constitution - is aimed in part at bridging this gap. European framework programmes constitute a large weight of investment in the transport research field and were meant to deliver cutting-edge, often policy-relevant insights that would contribute to the elaboration of key pieces of EU legislation to guide transport policies at other levels. It is to an analysis of this substantial body of research and its policy relevance with regard to social cohesion that we now turn.

\section{Social Cohesion in European Transport Research}

There is no doubt that the substantial EU funding from various Directorates-General for transport research in the past two decades has helped to advance thinking and knowledge in many areas. It has indeed generated a great deal of output, particularly with regard to various technologies such as telematics applications, to the extent that it itself demands various forms of meta-analysis, through the Transport Research Knowledge Centre for example, to distil it for users. Yet it also has significant gaps, is driven by particular disciplinary areas, fetishes best practice without a deeper understanding of the contexts of such practice (we discuss this in section 4) and distorts the European research field by funding some things at the expense of others. We argue that European Commission transport research has done much to perpetuate and maintain dominant research paradigms, to the detriment of social cohesion issues.

In general, much of the research is dominated by a technology focus, such as through research on materials, fuel technologies, telematics and incremental improvements to public transport systems. Although a number of projects, often intimately tied up with demonstration programmes, have addressed the transport needs of mobility-poor populations-for example, by promotion and deployment of flexible transport services such as demand-responsive transport (DRT) or shared taxisthey were rarely linked to research addressing cohesion in a more systemic way. Several research projects clustered within the land use and transport research (LUTR) theme, focused mainly on the links between urban mobility, spatial planning and environmental sustainability, have made an explicit contribution to social cohesion research in its various dimensions. Although social issues, such as equity, health, security and fear were considered as being important, these projects have, however, not provided an integrative analytical framework for social cohesion and have failed to operationalise social values (Kaufmann and Risser, 2004). Where a step forward in researching the impacts of urban transport on social exclusion and inclusion has been made (for example, Council of Europe, 2005; Latuso et al., 2004; and MATISSE, 2003), there seems to have been little influence on subsequent EC research, policy or disciplinary practices.

Another problem in fostering social cohesion through urban transport has arisen as a result of contradictions between social justice concerns and mainstream sustainability agendas. While the two agendas often overlap, this is by no means guaranteed, as sustainable city debates have been interpreted narrowly in research programmes with the social dimension overlooked or subsumed into a green 
agenda. After some pioneering work in urban transport research for policy-making that had a deep sense of social cohesion behind it in the early 1990s this has been largely crowded out latterly by a focus on the greening of the transport sector and carbon reduction in particular. The 'green' has supplanted the 'red' in research as the reduction of energy use in transport is often pursued through investigating more energy-efficient, yet often more expensive (and therefore potentially more exclusionary), fragmented and unbundled infrastructures (Graham, 2000). This combined with a technology fixation implies that very few analyses have systematically addressed how investment patterns from the public and private sectors work, individually and collectively, to favour certain social groups and certain localities and thus how social cohesion is achieved in and through the field of mobility, and transport investment specifics in particular. In short, the pursuit of new technological advances absorbs a great deal of resource with little analysis of how it affects social justice concerns.

\section{Social Cohesion in Transport Policy and Policy-oriented Research}

A great deal of work spread over several framework programmes has attempted to aid policy-makers by focusing on institutional questions of policy implementation in the transport field. A normative driver of this is typically to implement policy packages that are more environmentally friendly with cohesion issues sometimes addressed - and sometimes addressed well as, for example, in CAPTURE (1999). There have been several preliminary Europe-wide attempts to assess the implementation gap of urban transport planning support tools as in LUTR cluster projects or in the ECMT (2002) study on implementing sustainable urban travel policies. Central to such positive developments have been city networks, such as the POLIS network of European cities and regions, the European Metropolitan Transport Authorities network and EUROCITIES with its strong presence in work on mobility through the CIVITAS initiative, which collaborate to develop and support the implementation of innovative technologies and policies for local transport. These networks also provide arenas for dialogue and cooperation over the longer term, an essential prerequisite for understanding the contexts in which best practice might be learned and transferred (Stead et al., 2007).

Such work feeds into the fine words contained in several European Commission and Council of Europe documents that highlight urban mobility issues (for example, COM, 2001, 2007). Social cohesion issues (such as basic passenger rights and problems of passengers with reduced mobility) are reflected in guidance for national and local transport policy agendas, and key principles for supporting public transport are set out. It must be said, however, that there is little evidence that these documents influence much national and local practice. Further, despite considering socially cohesive urban transport as important, they are rather silent on the social implications of the polarisation of mobility opportunities in cities across Europe, especially failing to note that other EU policies and programmes often act against such objectives in, for example, supporting the development of new infrastructures and technologies, such as high-speed rail and electric vehicles, which tend to be unevenly exploited by wealthier groups.

Thus, following NICHES (2005), we argue that there is no lack of tools or of knowledge of policy (packages) that might be cohesion-promoting. Rather, it is the failure to utilise the tools and knowledge in many practice contexts and the insufficient intersectoral co-operation in current research and policymaking activities that are significant. One of the major reasons for this is a lack of wider interdisciplinarity going beyond and set against dominant disciplines such as engineering and economics that drive both the studies commissioned in European and other research programmes. Another reason lies in the attitudes of transport policy-makers, who-in searching for easily 
implementable transport solutions rather than long-term comprehensive policies—seek often-narrow, single-technolgy solutions that can be readily sold to politicians.

Although there is a vast literature on social aspects of transport systems in social research, and a progressing body of knowledge on social cohesion in contemporary transport geography, this research is often considered too complex and uncertain to be utilised by policy-makers. As a result, rather than exploring the diversity of urban contexts, getting new insights and perhaps even fully fledged approaches, transport policies are often based on 'commonsense' assumptions underpinning economic modelling and technological development (DfT, 2004). Within this, there is a strong influence of highly quantitative cost-benefit analysis and a focus on new transport technologies, procedures and products. In a similar vein, the obsession with best practice and toolkits, while useful as a starting-point, often fails to translate to the diversity of situations European policy-makers find themselves in. Policy agendas for socially cohesive transport are being discussed at various scales from local to city, national and European levels, often through scenario development and testing, using a lot of best practice examples, particularly at the local and city scales. However, little attention is given to the morphological, technical and institutional dynamics of context (Pflieger et al. 2007), and thus transferability, or to the political rationalities and governmental technologies of implementation. Also, not enough consideration is given to social analysis that would look into the interests of particular groups favouring certain transfers (Bulkeley, 2006), on the one hand, and to mobility behaviours and needs of diverse urban populations, on the other.

Relatedly, despite considerable development in recent years, policy evaluation mechanisms often experience serious problems in addressing broader definitions of social cohesion. Since it is not urban transport, but human mobility that builds a cohesive urban society, transport policy needs more explicit links to social analyses. Critical reflection on social cohesion issues related to urban transport requires intensified efforts to develop theoretical frameworks for the integration of existing qualitative and quantitative empirical studies presently dispersed across a variety of disciplines and traditions, and for the inclusion of transport problems into more general debates on society and space relations within social theory. The emerging mobilities paradigm (see Sheller and Urry, 2006; Jensen, 2009; Cresswell, 2010; Bissel, 2010) is a step forward in that direction. Yet the major question still lies in how to make social analysis work together with transport studies and urban planning, and if, how and to what extent the generated knowledge may be utilised by transport policy-makers and planners to favour more cohesive urban societies (Shaw and Hesse, 2010). This is also a challenge of communication wherein the work performed in such analyses is not easily interpreted by time-pressed public officials or indeed sold well to other research communities.

\section{Mobilising and Deepening the Social Cohesion Concept in Urban Transport Research}

To address these issues, we argue for a departure from fragmented, techno-modernist policy and policyoriented transport research aimed at predominantly technology-led solutions to societal problems towards a comprehensive agenda for urban mobility that is more sensitive to socio-political contexts and promotes social cohesion to the heart of not only mobility policies, but also research and professional and academic practices. This section sets out ideas for transdisciplinary transport research that could work towards more cohesive urban societies by linking just considerations of socioeconomic and spatial accessibility with the recognition of urban mobility as a domain of meaningful social experience. Such transdisciplinary research would examine complex relationships between transport solutions, on the one hand, and urban mobility patterns of individuals and specific needs of populations, 
on the other hand. Following a transdisciplinary path, it would also involve academic, policy and practice communities in a shared learning process that could shape and evaluate socially cohesive transport policy and practice and, in consequence, generate positive impacts on territorial and social integration, local and regional market economies and community life, as well as political and social governance of the non-economic sections of society.

Our urban mobility research agenda, which offers only a first step in this direction, is grounded in the analysis of multidimensional relationships between society, land use and transport (Geurs et al., 2009) to encompass

1) recognition of the diversity of socioeconomic and cultural contexts where particular transport systems are in operation;

2) examination of socio-subjective aspects of urban mobility and individual behavioural patternsfor example, making attempts to capture 'suppressed' journeys;

3) a critical focus on the relationships between transport policies and land use;

4) involvement with a variety of stakeholders and communication platforms for negotiation of progressive transport policies; and

5) mediating conflictive discourses on urban transport and encouraging policy-makers to defend socially cohesive solutions.

\subsection{Sensitivity to Context}

First, urban mobility research and innovative transport policy solutions need to be more sensitive to the social, cultural and economic conditions of the city. New innovative developments, just as social innovations of any kind, require testing against local cultures, historical trajectories, institutions, ecological conditions and behavioural patterns (Moulaert and Nussbaumer, 2005; Geels, 2002) and what Raymond Williams (1973) calls the 'structures of feeling' of the city. Thus, differences between the impacts of local policies on specific local populations, as well as cases of successful and unsuccessful policy transfers and the conditions under which transfer occurred and was modified, should be carefully examined. ${ }^{1}$ Fast mass transit systems, for example, have proved to be effective and cohesive transport solutions in densely urbanised areas, especially where land use and transport planning are well integrated. However, in other cities, in the mega cities of the global South in particular, especially where governance capacity is low, self-organising solutions such as paratransit and the informal sector may be less socially divisive and thus more appropriate (see Cervero, 2000; World Bank, 2002; Maricato, 2000). To assess which approach might work demands analysis of the particular socio-cultural context. For example, European transport research would benefit from comparative studies on mobility practices in other geo-regions with regard to the transport needs and behavioural patterns of ethnic migrants, who constitute a large share of mobility-poor populations in European cities. In gender terms, for instance, women suppress journeys associated with personal health care to fulfil other roles and demands in timepoor situations (Pearson et al., 2007). Researching cultural mobility backgrounds and the ethnic biases leading to underuse or rejection of certain transport modes - for example, among migrant women whose mobility exclusion arises predominantly from social relations within and outside their ethnic communities - could help in developing cohesive transport solutions for migrants and understanding what might work in a particular place (see Law, 1999; Harms, 2007; Uteng, 2008).

\subsection{Researching the Individual}

This leads us to the second argument - that progressive research should examine the urban mobility patterns of individuals and the complexity of their transport choices. Although past research has shown 
a considerable interest in individual-oriented approaches to transport planning, this interest was usually limited to 'objective' factors - that is, the investigation of the relationships between objective variables such as age, household characteristics and educational level, on the one hand, and mobility behaviour, on the other (Götz, 2009). Present research, particularly within the new mobilities paradigm, increasingly explores both the subjective factors shaping people's everyday practices, such as personal travel experiences and the construction of subjects in and through movement (for example, Richardson and Jensen, 2008; Sheller and Urry, 2006; Lévy, 1999), and socio-subjective factors, such as urban lifestyles and socio-cultural action patterns in space (for example, Kaufmann et al., 2004; Flamm, 2003) as well as the significance of household-level constraints. Although these factors are harder to measure, and thus are often overlooked by policy-makers, they are crucial to understanding individual (im)mobilities and the formation of socially cohesive societies.

With regard to social cohesion issues, research challenges in this area would include, amongst others

1) qualitative analysis of the relationships between transport networks and everyday life patterns relating to work and leisure activities, consumption patterns, family life, friendships and involvement of individuals in civic life, and connectedness to diverse social groupings at various urban scales;

2) examination of individual perceptions of spaces, distances between locations, mental mappings of urban space and conceptualisations of the city as a whole in regard to time budgets and financial constraints;

3) reflection on desirable and imagined mobilities from the perspective of the user; and

4) comparative studies of mobility levels and 'absences' and, in particular, reasons why certain networks are avoided by vulnerable groups and why levels of mobility remain low among certain groups.

Theoretical advances in recent studies on everyday urban mobility provide several valuable conceptual frameworks for such research. Particularly useful for analyses of social cohesion might be Kaufmann et al.'s concept of 'motility'. This is defined as "the capacity of entities (e.g. goods, information or persons) to be mobile in social and geographic space or as the way in which entities access and appropriate the capacity for socio-spatial mobility according to their circumstances" (Kaufmann et al., 2004, p. 750). Motility encompasses three interdependent factors conditioning personal urban mobility-access, competences and appropriation-giving high importance to socio-subjective conditions of one's mobility patterns focusing on "the logic of an actor's actions, in particular the reasons behind the choice of tools and localisations, without being concerned with an action's maximum utility" (Flamm and Kaufmann, 2006, p. 169). The distribution of mobility opportunities across the urban population, then, is of a plural nature and, therefore, socially cohesive transport solutions should be aimed not only at improving socioeconomic and spatial accessibility of transport services, but also at strengthening the competences of individuals and empowering appropriation.

Furthermore, the investigation of socio-subjective aspects of urban mobility is crucial to the analysis of the relationship between transport systems and different dimensions of social cohesion (Novy et al., this issue), as well as between spatial and social mobility. On the one hand, negotiation of practised mobilities between mobile subjectivities and structures of the city undermines the totality of socially exclusive or inclusive urban systems. On the other, this negotiation process also involves the construction of individual subjects through transport systems and planning imaginaries (Richardson and Jensen, 2008; Lévy, 1999) and, when considering motility as a social capital exchangeable to other capitals, reflects the links between spatial and social mobility and represents how the new social 
inequalities are being produced through transport systems (Kaufmann et al., 2004; Kesserling, 2004; Montulet, 1998). Hence, adding new transport solutions might mean, as in the case of the Bangkok Sky Train, not only connecting some places and disconnecting and marginalising others, broadening some and splintering other visual urban landscapes, empowering travel opportunities of the mobility-rich and disempowering opportunities of mobility-poor, but also reinforcing existing, and adding new socially stratifying layers to the city (Richardson and Jensen, 2008). Conversely, both inclusive transport policies and innovative strategies strengthening the socio-subjective mobility capabilities of individuals, may help to link them to diverse forms of 'spatial capital' (Lévy, 1994) and to enhance their 'network capital' (Urry, 2007) through bonding them with broader networks that offer financial and emotional benefits. Furthermore, mobility opportunities that are broadly distributed across social strata may strengthen not only the social inclusion of individuals, but may also foster the social cohesion of the urban whole, which - in urban societies "organised around distance and circulation" (Urry, 2007, p. 52) - is constituted by multiple overlapping networks and connections between individuals, social groupings and places.

\subsection{Transport and Land Use}

Thirdly, transport research should provide insights for the development of cohesive urban environments through bridging transport policies with land use. There is already a significant body of knowledge on this topic, which recommends mixed land use patterns and high densities in cities to help reduce the need for energy-intensive movement, as well as to counteract the spatial mismatch between low-income jobs and poor households. Mixed and compact land use patterns, which lead to a reduction in the need for trips, are put forward especially in poor neighbourhoods and include the improvement of the quality of existing facilities (schools, hospitals, etc.) and the creation of locally related job and leisure opportunities (for example, Geurs and van Wee, 2004; Sheller, 2008). Walkability in particular has a potential to foster social cohesion through its positive impacts on social connectedness, social order and safety, involvement with local community, health and wellbeing (Nasar, 2003; Kim and Kaplan, 2004). There is a need for more research and political attention to the cohesion impacts of 'walking-first' transport strategies, for example.

Within this analysis, the concentration of the vulnerable in certain urban areas has some benefits from a transport perspective, as it enables more effective delivery of solutions, whereas scattered manifestations of mobility poverty throughout the city make potential solutions less effective (Roth, 1984; Forckenbrock et al., 2001). Such concentrations - although they might raise issues relating to tensions between social cohesion at the neighbourhood and city scales, as well as undermine the delivery of cohesion promoting policies in other urban fields, such as education - can lead to the successful implementation of both targeted public transport policies and self-help solutions, such as car sharing, community mini-buses, etc.

Probably the most challenging research area that emerges in-between spatial planning and transport policy in regard to social cohesion concerns the way in which transport infrastructures can function as public spaces. Urban transport hubs, far from being 'non-places' (Augé, 1992) can be spaces with a high and unique potential for the establishment of the public realm (Bertolini, 2006). These 'spaces of flows' (Castells, 2001) are often the most intensively used spaces in contemporary cities, contain the highest degree of diversity among users and the highest level of human co-presence. Bus interchanges, railway stations, airports, underground stations and car parks, as well as trains and buses, attract artists, protesters and spokespeople of various sorts and function as meeting places and spaces for the exchange of ideas and images for those often excluded from the increasingly privatised parts of the urban realm 
(Bertolini, 2006). This potential of public transport hubs and vehicles, which has been greatly overlooked by researchers from all disciplines and backgrounds, calls for scientific investigation and exploration by policy and practice communities. Spaces of urban transport constitute crucial 'social condensers' (Jensen, 2009) of urban life - always classed, gendered, sexualised and racialised — where physical movement, corporeal travel and bodily experience intersect with various expressions of diversity, social interaction and identity formation. The recognition of experiential qualities of public transport interchanges and vehicles calls on the communities of practice to treat transport spaces more holistically and consider the embedding of the social qualities of urban travel in urban planning and design (see Bertolini, 2006; Cresswell, 2010).

\subsection{Engagement}

Fourthly, future transdisciplinary transport research should involve a variety of stakeholders: urban policy-makers and city users in particular. This research needs to evolve with continuous feedback from knowledge users to knowledge developers, and thus enable constant refining of new transport solutions, responding to challenges that arise in policy and practice domains, and allowing for a flow of 'lay' knowledge into practice communities (Bertolini, 2006). This involves new transdisciplinary approaches to the collection and analysis of data to include not only quantitative but also qualitative studies of everyday mobility with policy-makers and end users analysing the data and reshaping research directions, as well as an intersectoral production of knowledge and dialogue.

Foremost, research of this kind requires the creation of social platforms operating at multiple spatial scales which would enable communication between stakeholders from different backgrounds with plural stakes in various urban domains. Such participative endeavour requires not only transdisciplinary research that integrates academic knowledge with the technical skills and experience of policy-makers and lay knowledge of end users, but also transdisciplinary policy-making whereby academics, policymakers and lay people could jointly examine the mobility needs of certain populations, explore different scenarios, evaluate transport strategies and shape new policies through open expression for or against particular solutions.

\subsection{Mediation between Conflictive Policy Discourses}

Promoting an agenda of social cohesion is problematic in transport policy and planning and, as in all policy areas, requires constant political attention, putting into dialogue conflictive discourses and, at least sometimes, encouraging policy-makers to take a stand towards defending socially cohesive solutions. Much urban policy is framed by a neo-liberal discourse of economic competitiveness which in the field of transport is strongly attached to discourses of congestion that in turn are backed up by demands for supply-side interventions, themselves bolstered by the disciplines of engineering and economics, with 'travel time savings' put forward as major objectives of urban transport (Metz, 2008). An ecological discourse has been partly successful in getting traction in many urban transport discussions, but we do note a gap between rhetoric and action here (for example, Low and Gleeson, 2003; Vigar, 2002). On the one hand, social cohesion issues have benefited a little from being in a winwin coalition with environmental factors in policies such as pedestrianisation schemes, which usually lead to a modal shift from motorised to non-motorised mobility while simultaneously encouraging exchange, conviviality and movement for low-income groups. On the other, socially cohesive transport solutions often tend to be crowded out by mainstream sustainability agendas that prioritise the growth of the 'global green economy' and carbon reductions at wider scales over local social and socioenvironmental justice concerns (see Cook and Swyngedouw, this issue). 
The role of transport researchers lies here in the production of methodologies to investigate the benefits from a more socially cohesive transport policy, for example, the labour market benefits of improved transport networks or the ways in which such improvements support care arrangements. Finally, in cases of inherent conflicts of interests, transport research should critically enhance awareness of the social impacts of transport systems and antagonise the existing status quo in European cities where powerful groups, often unconsciously, exert control over space through influencing transport supply (Baeten, 2000). New deeply political transdisciplinary transport research and practice are needed to place social cohesion at the heart of transport policy through the development of "a completely new ethical and human rights perspective on transport and [to] test transport decisions and policy-making procedures on their ethical and human rights implications" (Whitelegg and Haq, 2003, p. 289). This should expose the transport planner not as a morally neutral technician but as a practitioner engaged in ethical questions posed through policy design, evaluation and implementation.

\section{Implications for Transport Policy}

Our discussion of the socially cohesive urban mobility agenda was limited to only a few crucial issues relating to the multidimensional relationships between society, land use and transport, thus our challenges and suggestions for comprehensive transport studies are also incomplete and require further deepening and long-lasting qualitative investigation that would supplement quantitative surveys and mathematical modelling.

First, new forms of assessment are needed. Transport policy that considers the broader objectives of public policy is a first step and is a reality in many nations (for example, Haq, 1997). At a more micro level, social cost auditing that would involve qualitative approaches and address the values of local communities has long been talked of in transport planning but often opposed as intangible and thus rarely implemented. And how assessment is done is also critical. The long-term generalised - direct and indirect-social, environmental and economic benefits and costs of planned transport network improvements should be included or-in particular cases, as methodologies for monetising social benefits and costs are always arbitrary - simply be put upfront in the decision-making process.

Secondly, best practice examples in transport policies, which are frequently regarded as key drivers of transport innovation and numerously produced across Europe under EU funding, should be tested against social, cultural, economic and spatial contexts where they are to be implemented. "Are there 'best practices' which are convertible like currencies? If not, how and to what extent must one take account of specific circumstances?" (Güller, 1996, p. 25). Moreover, the deployment of best practices should be followed by studies on the nature of policy interpretations and contextualisation, as well as on expected and unexpected consequences of transfers.

Thirdly, the visions of urban planners and agendas of transport policy-makers should be tested against local mobility patterns including research on the travel experiences of those who use existing networks and those who cannot or do not in regard to the seven-fold categorisation of the ways in which social exclusion arises, as pointed out by Church et al. (2000). This could incorporate the more recent work on motility, space and social cohesion expressed by Kauffmann et al. (2004), Bertolini (2006) and Richardson and Jensen (2008) among others, which might in turn bring broad cohesion issues arising from urban travel into research and policy-making. 
Last but not least, social platforms for practitioner and stakeholder involvement should be supported and created as part of implementing a debate on new socially cohesive urban transport solutions, and used for discussing and promoting behavioural change and more socially just mobility lifestyles.

\section{Conclusions}

This paper has sought to explore the multidimensional relations between social cohesion, transport and mobility. In doing so, it has examined the links between social justice concerns that highlight rising unevenness in the distribution of mobility opportunities across space and social strata, and broader social issues relating to social cohesion in the city as a whole. First, we showed how the urban mobility opportunities of individuals depend on increasingly complex and dynamic sets of economic (i.e. financial accessibility to urban transport services), cultural (with ethnic, gender and 'motility' components) and political (i.e. political regimes underpinned by different policy discourses) factors. Secondly, we pointed to multiple potentials embedded in urban mobility, which is not only a key to access to work, education and health, and the social mobility of individuals, but also provides 'a channel' to social interaction, the integration of urban society and the political activisation of citizens across urban space. This is increasingly explored within the 'new mobilities' paradigm as a meaningful socio-political space of the everyday wherein collective identities and social affinities are negotiated.

However, despite an explicit concern of policy-makers with social cohesion issues and the emergence of new streams of inquiry in transport studies that innovatively link urban mobility to broader social issues, socially cohesive transport solutions are rarely turned into practice. We argue that policy-making still relies mostly on single-modal, technology-led research. The large sums deployed in such research, at the EC level in particular, are part of the problem, creating a weight of work and a mass of researchers and research communities in certain domains, to the crowding-out of other areas. Moreover, a focus on technology-led solutions, that are seen by many policy-makers as carriers of political capital and as a magic bullet for both provision of efficient transport networks and meeting the carbon reduction goals of mainstream sustainability agendas, tends to depoliticise the domain of urban transport. Conversely, embedding social cohesion within transport research and policy requires exploring the social, cultural, political and spatial conditions and opportunities arising from urban mobility, the development of new context-sensitive methods for assessing transport networks and proposed improvements, and a political will to put them into motion. The yet-emerging agenda for transport research and policy that we presented in sections 5 and 6 of this paper-which embraces sensitivity to context, researching the socio-subjective aspects of mobility, investigation of relations between transport and land use, engagement of stakeholders and mediation between transport policy discourses-calls for a transdisciplinary endeavour that would bridge academic, policy and practice communities in a shared learning process geared at building more cohesive urban societies.

\section{Acknowledgements}

The authors would like to thank Matteo Colleoni, Steve Graham, Frank Moulaert, Dominic Stead, and Esik Swyngedouw for comments on earlier drafts of this paper. They would also like to thank Andy Cumbers and the anonymous referees for critical and constructive guidance. 


\section{Notes}

1. See the special issue of Transport Policy 18(2).

\section{Funding Statement}

This research was supported by the European Commission, 7th Framework Programme grant SOCIAL POLIS ‘Social Platform on Cities and Social Cohesion' (grant number 217157).

\section{References:}

Augé, M. (1992) Non-lieux: Introduction à une anthropologie de la surmodernité. Paris: Le Seuil.

Baeten, G. (2000) The tragedy of the highway: empowerment, disempowerment and the politics of sustainability discourses and practices, European Planning Studies, 8(1), pp. 69-86.

Banister, D. (2005) Unsustainable Transport. London: Spon.

Beckmann, K. J., Bracher, T., Hesse, M. (2007a) Editorial: urban mobility and social inequity, Deutsche Zeitschrift für Kommunalwissenschaften, 46(2), pp. 5-8.

Beckmann, K. J., Bracher, T., Hesse, M. (2007b) Mobility and deprived urban neighbourhoods in the focus of integrated urban development policy, Deutsche Zeitschrift für Kommunalwissenschaften, 46(2), pp. 9-22.

Bertolini, L. (2006) Fostering urbanity in a mobile society: linking concepts and practices, Journal of Urban Design, 11(3), pp. 319-334.

Bissel, D. (2010) Passenger mobilities: affective atmospheres and the sociality of public transport, Environment and Planning D, 28, pp. 270-289.

Bonss, W., Kesselring, S. (2001) Mobilität am Übergang von der Ersten zur Zweiten Moderne, in: Beck, U., Bonss, W. (Eds) Die Modernisierung der Moderne. Frankfurt am Main: Suhrkamp Verlag.

Bulkeley, H. (2006) Urban sustainability: learning from best practice?, Environment and Planning A, 38(6), pp. 1029-1044.

Bullard, R., Johnson, S., Torres, A. O. (2004) Highway Robbery: Transportation Racism and New Routes to Equity. Cambridge, MA: South End Press.

Canon, D. T. (1998) Race, Redistricting, and Representation: The Unintended Consequences of Black Majority Districts. Chicago, IL: University of Chicago Press.

CAPTURE (1999) Cars to public transport in the urban environment. CAPTURE final summary report, EUTransport RTD Programme.

Castells, M. (2001) The Rise of the Network Society. Oxford: Blackwell.

Cervero, R. (2000) Informal Transport in the Developing World. Nairobi: UN-HABITAT.

Church, A., Frost, M., Sullivan, K. (2000) Transport and social exclusion in London, Transport Policy, 7, pp. 195-205.

COM (Commission of the European Communities) (2001) White Paper: European transport policy for 2010: time to decide. COM, Brussels.

COM (2007) Green Paper: towards a new culture for urban mobility. COM, Brussels.

Cook, I. R., Swyngedouw, E. (2012) Cities, social cohesion and the environment: towards a future research agenda, Urban Studies, 49(9), pp. 1959-1979.

Council of Europe (2005) Concerted development of social cohesion indicators: methodological guide. Council of Europe, Strasbourg.

Cresswell, T. (2010) Towards a politics of mobility, Environment and Planning D, 28, pp. 17-31.

Danyluk, M., Ley, D. (2007) Modalities of the new middle class: ideology and behaviour in the journey to work from gentrified neighbourhoods in Canada, Urban Studies, 44(11), pp. 2195-2210.

DfT (Department for Transport) (2004) Review of social research in the Department for Transport. DfT, London.

ECMT (European Conference of Ministers of Transport) (2002) Implementing sustainable urban travel policies: final report. ECMT, Paris.

Flamm, M. (2003) Comprendre le choix modal: les déterminants des pratiques modales et des représentations individuelles des moyens de transport. Lausanne: Presses polytechniques et universitaires romandes. 
Flamm, M., Kaufmann, V. (2006) Operationalising the concept of motility: a qualitative study, Mobilities, 1(2), pp. 167-189.

Forckenbrock, D. J., Benshoff, S., Weisbrod, G. E. (2001) Assessing the social and economic effects of transportation projects. University of Iowa/Economic Development Research Group, Boston, MA.

Geels, F. W. (2002) Technological transitions as evolutionary reconfiguration processes: a multi-level perspective and a case-study, Research Policy, 31(8/9), pp. 1257-1274.

Geurs, K. T., Wee, B. van (2004) Accessibility evaluation of land-use and transport strategies: review and research directions, Journal of Transport Geography, 12, pp. 127-140.

Geurs, K. T., Boon, W., Wee, B. van (2009) Social impacts of transport: literature review and the state of the practice of transport appraisal in the Netherlands and the United Kingdom, Transport Reviews, 29(1), pp. 69-90.

Götz, K. (2009) The interdependence of 'subjective' and 'objective' factors: socio-cultural distance patterns and 'social accessibility' as categories of empirical mobility research, in: Holz-Rau, C., Scheiner, J. (Eds) Subject-oriented Approaches to Transport, ch. 3. Dortmund: IRPUD.

Graham, S. (2000) Constructing premium network spaces: reflections on infrastructure networks and contemporary urban development, International Journal of Urban and Regional Research, 24(1), pp. 183200.

Graham, S., Marvin, S. (2001) Splintering Urbanism: Networked Infrastructures, Technological Mobilities and the Urban Condition. London: Routledge.

Grieco, M., Macdonald, K. (2007) Accessibility, mobility and connectivity: the changing frontiers of everyday routine, Mobilities, 2(1), pp. 1-14.

Güller, P. (1996) Urban travel in east and west: key problems and a framework for action, in: ECMT (Eds) Sustainable Transport in Central and Eastern European Cities, pp. 16-43. Paris: ECMT.

Hägerstrand, T. (1974) The impact of transport on the quality of life. Lunds Universitets Kulturgeografiska Institution.

Haq, G. (1997) Towards sustainable transport planning. Aldershot: Ashgate.

Harms, L. (2007) Mobility among ethnic minorities in the urban Netherlands, Deutsche Zeitschrift für Kommunalwissenschaften, 46(2), pp. 78-94.

Häussermann, H. (2000) Die Krise der sozialen Stadt, Aus Politik und Zeitgeschichte, B(10/11), pp. 13-21.

Hine, J., Grieco, M. (2003) Scatters and clusters in time and space: implications for delivering integrated and inclusive transport, Transport Policy, 10, pp. 299-306.

Hine, J., Mitchell, F. (2003) Transport Disadvantage and Social Exclusion. Ashgate: Aldershot.

Jain, J., Lyons, G. (2008) The gift of travel time, Journal of Transport Geography, 16(2) pp. 81-89.

Jarvis, K. (2005) Moving to London time: household co-ordination and the infrastructure of everyday life, Time \& Society, 14(1), pp. 133-154.

Jensen, O. B. (2009) Flows of meaning, cultures of movements: urban mobility as meaningful everyday life practice, Mobilities, 4(1), pp. 139-158.

Kaufmann, C., Risser, R. (2004) Synthesis report: social aspects. Planning and urban mobility in Europe (PLUME) (http://www.factum.at/PDFuDoc/SR_Social_aspects_v1.2.pdf).

Kaufmann, V., Bergman, M. M., Joye, D. (2004) Motility: mobility as capital, International Journal of Urban and Regional Research, 28(4), pp. 745-756.

Kemming, H., Brinkmann, W. (2007) Verkehrsverhalten sozialer Gruppen: Soziale Aspekte der Mobilität. Institut für Landes- und Stadtentwicklungsforschung und Bauwesen des Landes NRW, Dortmund.

Kesselring, S. (2004) Bewegliche Identitäten: Chancen und Risiken der Mobilität, Durchblück: Zeitschrift für Ausbildung, Weiterbildung und berufliche Integration, 4(44).

Kim, J., Kaplan, R. (2004) Physical and psychological factors in sense of community, Environment and Behavior, 36, pp. 313-340.

Latuso, K.. (2004) PROPOLIS: Planning and research for land use and transport for increasing urban sustainability: final report. Kuopio: LT Consultants Ltd.

Law, R. (1999) Beyond 'women and transport': towards new geographies of gender and daily mobility, Progress in Human Geography, 23(4), pp. 567-588.

Lévy, J. (1994) L’Espace Légitime. Paris: Presses de la Fondation Nationale des Sciences Politiques.

Lévy, J. (1999) Le tournant géographique. Paris: Armand Colin. 
Lin, J. (2002) Gentrification and transit in north-west Chicago, Transportation Quarterly, 56(4), pp. 175-191. Low, N., Gleeson, B. (2003) Making Urban Transport Sustainable. Basingstoke: Palgrave.

Lucas, K., Stanley, J. (2003) International perspectives on transport and social exclusion, Transport Policy, 10(3), pp. 89-142.

Lyons, G. (2009) The reshaping of activities and mobility through new technologies, Journal of Transport Geography, 17, pp. 81-82.

Maricato, E. (2000) Urbanismo na periferia do mundo globalizado: metrópoles brasileiras, São Paulo em perspectiva, 14(4), pp. 21-33.

Massey, D., Denton, N. (1993) American Apartheid: Segregation and the Making of the Underclass. Cambridge, MA: Harvard University Press.

MATISSE (Methodology for Assessment of Transport Impacts of Social Exclusion) (2003) Preparatory measures combating and preventing exclusion. Interim report, MATISSE project, Transport \& Travel Research, Woodstock.

Metz, D. (2008) The myth of travel time saving, Transport Reviews, 28(3), pp. 321-336.

Ministerstwo Infrastruktury (2004) Raport o stanie zagospodarowania przestrzennego kraju. Ministerstwo Infrastruktury, Warszawa.

http://scholar.google.com/scholar_lookup?hl=en\&publication_year=2004\&author=Ministerstwo+Infrastruktury \&title=Raport+o+stanie+zagospodarowania+przestrzennego+kraju

Montulet, B. (1998) Les enjeux spatio-temporels du social: mobilité. Paris: L’Harmattan.

Moulaert, F., Nussbaumer, J. (2005) The social region: beyond the territorial dynamics of the learning economy, European Urban and Regional Studies, 12(1), pp. 45-64.

Nasar, J. L. (2003) Does neotraditional development build community?, Journal of Planning Education and Research, 23, pp. 58-68.

NICHES (New and Innovative Concepts for Helping European Transport Sustainability) (2005) Innovative urban transport concepts. Inception report, NICHES (http://www.niches-transport.org/).

Novy, A., Coimbra Swiatek, D., Moulaert, F. (2012) Social cohesion: a conceptual and political elucidation, Urban Studies, 49(9), pp. 1873-1889.

Park, R. E., Burgess, E., McKenzie, R. (1925) The City. Chicago, IL: University of Chicago Press.

Pearson, M. A., Dawson, C., Moore, H., Spencer, S. (2007) Health on borrowed time? Prioritizing and meeting needs in low-income households, Health and Social Care in the Community, 1(1), pp. 45-54.

Pflieger, G., Kaufmann, V., Pattaroni, L., Jemelin, C. (2007) How does urban public transport change cities? Correlations between past and present transport and urban planning policies, Urban Studies, 46(7), pp. 1421-1437.

Preston, J., Rajé, F. (2007) Accessibility, mobility and transport-related social exclusion, Journal of Transport Geography, 15, pp. 151-160.

Pucher, J., Peng, Z., Mittal, N., Zhu, Y.. (2007) Urban transport trends and policies in China and India: impacts of rapid economic growth, Transport Reviews, 27(4), pp. 379-410.

Rajé, F. (2004) Transport, Demand Management and Social Inclusion: The Need for Ethnic Perspectives. Ashgate: Aldershot.

Richardson, T., Jensen, O. B. (2008) How mobility systems produce inequality: making mobile subject types on the Bangkok Skytrain, Built Environment, 34(2), pp. 218-231.

Roth, G. (1984) Improving the mobility of the urban poor, in: Richards, P. J., Thomson, A. M. (Eds) Basic Needs and the Urban Poor: The Provision of Communal Services, pp. 215-242. Beckenham: Croom Helm, Ltd.

SEU (Social Exclusion Unit) (2003) Making the connections. SEU, London.

Shaw, J., Hesse, M. (2010) Transport, geography and mobilities, Transactions of the Institute of British Geographers, 35(3), pp. 305-312.

Sheller, M. (2008) Mobility, freedom, and public space, in: Bergmann, S., Sager, T. (Eds) The Ethics of Mobilities: Rethinking Place, Exclusion, Freedom and Environment, pp. 25-38. Aldershot: Ashgate.

Sheller, M., Urry, J. (2006) The new mobilities paradigm, Environment and Planning A, 38, pp. 207-226.

Stead, D., Jong, M. de, Reinholde, I. (2007) Urban transport policy transfer in central and eastern Europe, disP, 172, pp. 62-73.

Terry, F. (2004) Transport: beyond predict and provide, in: Davies, H., Nutley, S., Smith, P. (Eds) What Works?: Evidence-based Policy and Practice in Public Services. pp. 189-206. Bristol: Policy Press. 
Urry, J. (2007) Mobilities. Cambridge, MA: Polity Press.

Uteng, T. P. (2008) Gendered mobility: a case study of non-Western immigrant women in Norway, in: Bergmann, S., Sager, T. (Eds) The Ethics of Mobilities: Rethinking Place, Exclusion, Freedom and Environment, pp. 73-102. London: Ashgate.

Vasconcellos, E. A. (2001) Urban Transport, Environment and Equity. London: Earthscan.

Vigar, G. (2002) The Politics of Mobility. London: Spon.

Whitelegg, J. (1997) Critical Mass. London: Pluto Press.

Whitelegg, J., Haq, G. (2003) New directions in world transport policy and practice, in: Whitelegg, J., Haq, G. (Eds) The Earthscan Reader on World Transport Policy \& Practice, pp. 275-296. London: Earthscan.

Williams, R. (1973) The Country and the City. London: Chatto and Windus.

Wirth, L. (1928) The Ghetto. Chicago, IL: University of Chicago Press.

World Bank (2002) Cities on the Move: A World Bank Urban Transport Strategy Review. Washington, DC: World Bank.

Zinnbauer, D. (2007) What can social capital and ICT do for inclusion? Institute for Prospective Technological Studies, Seville. 